\title{
Effects of Thermal and Ultrasound Treatments on L Ascorbic Acid of Grapes J uice
}

\begin{abstract}
MIRABELA IOANA LUPU, CARMEN LILIANA BADARAU*, VASILE PADUREANU, CRISTINA MARIA CANJ A
Transilvania University of Brasov, Faculty of Food and Tourism, 148 Castelului Str., 500014, Brasov, Romania

Improving the nutritional quality for non-alcoholic beverages (especially the content of valuable natural antioxidants) by using modern ultrasound treatments represent a challenge for more and more food scientists. The objective of this research work was to estimate the effect of some ultrasound treatments on the total $L$ ascorbic acid content and on several physicochemical characteristics of grape juice stored for different time periods. In order to determine this influence, the sonication parameters chosen were the amplitude $(60 \%, 80 \%)$ and the treatment times $(18,36 \mathrm{~min}$.$) . The samples treated by direct sonication$ (amplitude 80\%, 36 min.) and stored 17 days had higher values of total $L$ ascorbic acid content.
\end{abstract}

Keywords: $L$ ascorbic acid, grapes juice, ultrasound treatments

Fruit intake is recommended as part of a healthy diet and a practical way to do so is in form of juice. When fruit juices are produced on an industrial scale, the inactivation of microorganisms and enzymes is mandatory in order to guarantee safety and stability.

Thermal processing has been quite useful for that purpose. However, excessive heating induces physical and chemical reactions that negatively affect the sensorial and nutritional properties of this kind of food [1]. The application of ultrasound-assisted extraction for plant materials and its opportunities in the food industry has proved many advantages [2-5].

Ultrasound is reported to have a minimal effect on the quality of fruit juices [6].

One of the most important micronutrient present in the fruits juice is the $L$ ascorbic acid (vitamin $C$ ). Three main biological functions have been identified for compound: enzyme cofactor, free radical scavenger and donor/ acceptor of electrons. Humans have lost ability to synthesize $L$ ascorbic acid and depend on the diet to acquire the necessary amounts required to maintain good health. Deficiency of the vitamin C causes the disease scurvy characterized by spots on the skin, spongy gums and bleeding from mucous membranes. Is caused by deficient synthesis of collagen in which $L$ ascorbic acid is cofactor [7-9]. Although, nowadays, scurvy is considered rare in developed nations, the vitamin $\mathrm{C}$ intake of significant part of the population of some of these countries may be below recommended daily acceptance $(80 \mathrm{mg}$ per day in European Union EC) [10-12]. About 13\% of the population in the USA or 1 in 7 young adults in Canada have been reported to be deficient in vitamin $\mathrm{C}$ with certain groups such as smokers, pregnant women and people of low socioeconomic status at a higher risk of deficiency is common. $L$ ascorbic acid is particular important because it can reduce the chelating effect that some compound could have on iron, increasing its bioavailability [11]. Data reported by other researchers [13] revealed that the ultrasound treatments applied to different jus could inactivate microorganisms and increase antioxidants compounds. Therefore, the purpose of this study was to estimate the effect of ultrasound treatment on the level content of $\mathrm{L}$ ascorbic acid and on some physicochemical properties ( $\mathrm{pH}$, density, total soluble solids, titratable acidity, tartaric acid) of grapes juice during differentstorage periods.

\section{Experimental part}

Material and methods

Samples preparation

The experimental variants of juices were obtained from grape varieties Riesling (cultivated in the vineyard Dealu Mare, Romanian region and harvest at the end of September 2017). For obtain the juice, the grapes were first removed from the bunch and crushed with a crusher destemmer (Enoventa Tecnologie Enologiche, Italy). The next step was pressing the juice and solid particles with a hydraulic press machine (LU.C.M.E. Elettromeccanica, Italy). The juice was left for clearing for $4 \mathrm{~h}$ before starting the treatments.

Juice samples were treated by ultrasound (VCX-750, Sonics \& Materials, Inc. Newtown, CT, USA) at 750 W, with constant frequency of $20 \mathrm{kHz}$ at 60 and $80 \%$ amplitude for time periods of 18 or 36 min using a sample of $500 \mathrm{~mL}$ grape juice. This combination of amplitude and time was established according results of previous study, where a reduced of microbial count and release of antioxidant compounds was obtained [13].

Untreated juice was selected as control and pasteurized juice in a water bath at $70^{\circ} \mathrm{C}$ for $30 \mathrm{~min}$ [13], was also included to compare results. Samples were stored at $4^{\circ} \mathrm{C}$ and analyzed after 1, 4, 7, 10 and 17 storage days.

Determination of parameters quality, polyphenol and vitamin $C$ content

The $\mathrm{pH}$ was measured with a potentiometer (Consort C1010, Consort, Belgium).

The density $(\mathrm{g} / \mathrm{L})$ was measured with a densitometer standardized at $20^{\circ} \mathrm{C}$.

Total soluble solids content( ${ }^{\circ} \mathrm{Brix}$ ) was determined using a refractometer (Brix/ ATC FG-113, Hangzhou Chinchan Trading Co., China).

Titratable acidity was performing on aliquots of $10 \mathrm{~mL}$ placed into a $250 \mathrm{~mL}$ beaker and titration with sodium hydroxide 0.1N (Sigma-Aldrich, Dublin, Ireland). With a pipette, on a porcelain plate for titration, a drop of juice was removed and mix with two drops of indicator red phenol $0.02 \%$. The titration is continued drop to drop, after each addition of the sodium hydroxide solution, until the indicator turns in pink-orange. The results are expressed as $g$ tartaric acid/L. The titratable acidity $\left(A_{\top}\right)$ was calculated using the value of sodium hydroxide $0.1 \mathrm{~N}$ solution volume (V), as follows:

\footnotetext{
* email: carmen.badarau@unitbv.ro, Phone: 0730594687
} 


$$
A_{T}=\frac{V \cdot 0.0075 \cdot 1000}{10}=0.75 \cdot \mathrm{V} \quad \mathrm{g} \text { tartaric acid } / L
$$

The semnifications of symbols used in these relations are:

Tartaric acid content ( $\mathrm{g} / \mathrm{L}$ ) was determined following a colorimetric sequential technique (HI83748, Hanna Instruments).

The total phenols content was measured with an optical system of Hanna's HI 83000 series colorimeters. Photometric chemical analysis is based on the possibility to develop an absorbing compound from a specific chemical reaction between sample and reagents.

Extraction of $L$ ascorbic acid $(L-A A)$ was carried out by following steps (indicated by the manufacturer instructions - Megazyme Ltd., Sigma Aldrich, USA, cod product MAK074): adding $10 \mathrm{~mL}$ of $6 \%(\mathrm{w} / \mathrm{v})$ aqueous solution of meta phosphoric acid and $40 \mathrm{~mL}$ 1-octanol to $10 \mathrm{~mL}$ sample (variants of grapes juice treated and non-treated); vortex this mixture for $1 \mathrm{~min}$; adjust to $\mathrm{pH} 3.5-4$; quantitatively transferring to a $20 \mathrm{~mL}$ volumetric flask; centrifuge at $13.684 \mathrm{~g}$ ( $14.000 \mathrm{rot} / \mathrm{min}$.) for $5 \mathrm{~min}$. (a part of the mixture was taken in $1.5 \mathrm{~mL}$ tubes).

Determination of the $L$ ascorbic acid content was carried outusing the supernatant and an enzymatic method (L-ascorbic acid test kit, Megazyme Ltd., Sigma Aldrich, USA, cod product MAK074) following the instructions of the manufacturer. This method is based on the color change of the absorption caused by the reduction of 3 (4.5-dimethylthiazol-2)-2.5-diphenyltetrazolium bromide before and after ascorbic oxides is added, the concentration of $L$ ascorbic acid being proportional to this change. The absorbance was measured at $570 \mathrm{~nm}$ (Tecan SunRise micro plate reader, software Magellan). The determination was made in 5 repetitions at different time periods of the samples storage. The content of the L-AA was expressed as $\mathrm{mg} \mathrm{L}$ Ascorbic Acid per liter of juice ( $\mathrm{mg} \mathrm{L}-\mathrm{AA} / \mathrm{L}$ ).

\section{Results and discussions}

All the grapes juice treated by ultrasound had higher values of $L$ ascorbic acid content compared to the pasteurized and control samples (table 1). The juices samples treated by sonication at $80 \%$ amplitude for 36 min presented the highest value of vitamin $C$ content $(64.498 \pm 4.022 \mathrm{mg} \mathrm{L}-\mathrm{AA} / \mathrm{L})$. Pasteurized treatments led to a significant decrease of $L$ ascorbic acid content (compared to the untreated control) and after 17 storage days the juice had the lowest content in this phytochemical compound ( $23.990 \pm 6.509 \mathrm{mg} \mathrm{L-AA} / \mathrm{L})$.

Different researchers reported the most important mechanisms for explain the evolution and variations of vitamin $\mathrm{C}$ induced by the ultrasound during the storage. Maybe, the vitamin $\mathrm{C}$ breakdown is prevented by the elimination of dissolved oxygen (essential for ascorbic acid degradation), during the cavitations produced by the ultrasounds treatment [14]. Tiwari et al. [6] considered that the extreme physical conditions existing inside the cavitations bubbles collapsing in a micro scale and caused some chemical reactions that occur either in the same time or in isolation. Sonication cavities can be filled using water vapor and different gases dissolved in the juice, such as $\mathrm{N}_{2}$ which may aid oxidation reactions promoted by interactions with free radicals formed during sonication [15]. This oxidation could cause that ascorbic acid converts to dehydroascorbic acid [16] explaining the variations during storage.

Significant differences regarding the vitamin $C$ content were observed between the variants of treatment (table 1). So, the simple correlation coefficient Pearson revealed significantly higher value regarding the vitamin $\mathrm{C}$ content (as compared to the different treatment variants) (table 2). Our results revealed that ultrasound treatments, especially at $80 \%$ amplitude for $36 \mathrm{~min}$. had a grate effect on vitamin C content during storage. Ultrasound can be considered as an alternative emerging technology for grapes juice preservation, for increase the level of vitamin C content, maintaining the antioxidant properties. However,

Table 1

TOTAL L-ASCORBIC ACID CONTENT OF THE GRAPES JUICE TREATED AND UNTREATED AFTER DIFFERENT STORAGE PERIODS (DATA ARE MEAN OF THE VALUES \pm STANDARD DEVIATION)

\begin{tabular}{|c|c|c|c|c|c|}
\hline \multirow{2}{*}{$\begin{array}{l}\text { Variant of the } \\
\text { treatment }\end{array}$} & \multicolumn{5}{|c|}{ Storage days } \\
\hline & 1 & 4 & 7 & 10 & 17 \\
\hline Juice untreated & $\begin{array}{c}43.880 \pm 3.738 \\
(\mathrm{fgh})^{*}\end{array}$ & $42.425 \pm 7.397(\mathrm{gh})$ & $41.455 \pm 1.918(\mathrm{gh})$ & $42.182 \pm 2.921(\mathrm{gh})$ & $\begin{array}{c}39.272 \pm 4.236 \\
\text { (h) }\end{array}$ \\
\hline Pasteurized & $25.688 \pm 5.001$ (i) & $24.961 \pm 7.357(\mathrm{i})$ & $24.476 \pm 5.941$ (i) & $25.446 \pm 5.584$ (i) & $\begin{array}{l}23.990 \pm 6.509 \\
\text { (i) }\end{array}$ \\
\hline $\mathrm{A} 60 \%, 18 \mathrm{~min}$ & $\begin{array}{c}52.370 \pm 6.302 \\
\text { (de) }\end{array}$ & $49.217 \pm 5.259(\mathrm{efg})$ & $51.642 \pm 4.896$ (def) & $52.855 \pm 5.117$ (cde) & $\begin{array}{c}54.553 \pm 3.679 \\
\text { (cde) }\end{array}$ \\
\hline $\mathrm{A} 60 \%, 36 \mathrm{~min}$ & $\begin{array}{c}57.464 \pm 4.728 \\
\text { (abcde) }\end{array}$ & $54.796 \pm 3.209$ (cde) & $\begin{array}{c}55.038 \pm 2.766 \\
\text { (bcde) }\end{array}$ & $55.281 \pm 6.220$ (bcde) & $\begin{array}{c}57.464 \pm 3.254 \\
\text { (abcde) }\end{array}$ \\
\hline A $80 \%, 18 \mathrm{~min}$ & $\begin{array}{c}55.523 \pm 5.328 \\
\text { (bcde) }\end{array}$ & $53.098 \pm 6.279$ (cde) & $54.068 \pm 6.220$ (cde) & $56.251 \pm 3.473(\mathrm{abcd})$ & $\begin{array}{c}58.677 \pm 4.881 \\
\text { (abcd) }\end{array}$ \\
\hline $\mathrm{A} 80 \%, 36 \mathrm{~min}$ & $\begin{array}{c}57.949 \pm 3.986 \\
\text { (abcd) }\end{array}$ & $\begin{array}{c}59.162 \pm 4.666 \\
\text { (abcd) }\end{array}$ & $61.102 \pm 4.406(\mathrm{abc})$ & $63.528 \pm 4.059(\mathrm{ab})$ & $\begin{array}{c}64.498 \pm 4.022 \\
\text { (a) }\end{array}$ \\
\hline
\end{tabular}

${ }^{8}$ Values not followed by the same letter are significantly different $(\mathrm{P}=0.05)$ according to Duncan's test.

Table 2

THE CORRELATION BETWEEN THE CONTENT OF L ASCORBIC ACID (IN GRAPES JUICE TREATED AND UNTREATED AFTER DIFFERENT DAYS) AND THE VARIANT OF TREATMENT

\begin{tabular}{|l|c|c|c|}
\hline Variables & Statistical indicators & Days after treatments & Variant of the treatment \\
\hline \multirow{2}{*}{$\begin{array}{l}\text { Vitamin C } \\
\text { content (mg/L) }\end{array}$} & Correlation coefficient Pearson & 0.042 & $\mathbf{0 . 7 2 2}^{\mathbf{*}}$ \\
\cline { 2 - 4 } & Significance threshold & 0.612 & 0.000 \\
\cline { 2 - 4 } & $\mathrm{N}$ & 150 & 150 \\
\hline
\end{tabular}

${ }^{88}$ Correlation is significant for $\mathrm{p}=0.01$.

$\mathrm{N}=150$ (5 periods of storage $\mathrm{x} 6$ variants $\mathrm{x} 5$ repetitions) 
Table 3

MEAN ( \pm SD) VALUES OF PH, TOTAL SOLUBLE SOLIDS, TOTAL ACIDITY, TARTARIC ACID AND TOTAL PHENOL CONTENT OF GRAPES JUICES (DIFFERENT VARIANTS OF TREATMENTS) DURING STORAGE

\begin{tabular}{|c|c|c|c|c|c|c|c|}
\hline \multirow{2}{*}{$\begin{array}{l}\text { Type of } \\
\text { analysis }\end{array}$} & \multirow{2}{*}{$\begin{array}{l}\text { Stora } \\
\text { ge } \\
\text { days }\end{array}$} & \multicolumn{6}{|c|}{ Treatments } \\
\hline & & $\begin{array}{l}\text { Grape juice } \\
\text { untreated } \\
\text { (control) }\end{array}$ & $\begin{array}{l}\text { Pasteurized } \\
\text { juice }\end{array}$ & $\begin{array}{l}\mathrm{A} 60 \% \% \\
18 \mathrm{~min}\end{array}$ & $\begin{array}{l}\mathrm{A} 60 \% \% \\
36 \mathrm{~min}\end{array}$ & $\begin{array}{l}\text { A80\% } \\
18 \mathrm{~min}\end{array}$ & $\begin{array}{l}\text { A80\% } \\
36 \mathrm{~min}\end{array}$ \\
\hline \multirow{5}{*}{$\mathrm{pH}$} & 1 & $3.633 \pm 0.006^{x z}$ & $3.593 \pm 0.011^{b z}$ & $3.543 \pm 0.012^{\mathrm{cs}}$ & $3.536 \pm 0.015^{\mathrm{cs}}$ & $3.543 \pm 0.006^{c x}$ & $3.507 \pm 0.015 d z$ \\
\hline & 4 & $3.613 \pm 0.006^{25}$ & $3.590 \pm 0.010^{b z}$ & $3.537 \pm 0.006^{c} \gamma^{x}$ & $3.537 \pm 0.006^{c x}$ & $3.546 \pm 0.006^{c x}$ & $3.503 \pm 0.006^{d x}$ \\
\hline & 7 & $3.600 \pm 0.006^{2 x}$ & $3.573 \pm 0.006^{\circ y}$ & $3.527=0.006 \mathrm{c} \mathrm{y}$ & $3.517 \pm 0.006^{c y}$ & $3.523 \pm 0.006^{c y}$ & $3.487 \pm 0.006 \mathrm{dy}$ \\
\hline & 10 & $3.597 \pm 0.006^{2 x}$ & $3.563 \pm 0.006^{\circ y}$ & $3.507 \pm 0.006^{c x}$ & $3.493 \pm 0.006 \mathrm{dx}$ & $3.507 \pm 0.006^{c x}$ & $3.463 \pm 0.006^{\circ x}$ \\
\hline & 17 & $3.583 \pm 0.006^{2 x}$ & $3.543 \pm 0.006^{0 x}$ & $3.493 \pm 0.006^{\mathrm{cw}}$ & $3.483 \pm 0.006^{c x}$ & $3.487 \pm 0.006^{\mathrm{cw}}$ & $3.447 \pm 0.006^{c w}$ \\
\hline \multirow{5}{*}{$\begin{array}{c}\text { Total } \\
\text { soluble } \\
\text { solids } \\
\text { [ }{ }^{\circ} \text { Brix] }\end{array}$} & 1 & $24.37=0.058^{2 x}$ & $24.40=0.000^{2 x}$ & $23.73 \pm 0.058^{b z}$ & $23.67 \pm 0.115^{6 x}$ & $23.33 \pm 0.115^{c x}$ & $23.43 \pm 0.058^{c x}$ \\
\hline & 4 & $23.37 \pm 0.044^{25}$ & $23.04 \pm 0.574^{365}$ & $22.96 \pm 0.015^{\text {sta } y}$ & $22.78 \pm 0.021^{60 y}$ & $22.55 \pm 0.044^{c y}$ & $22.63 \pm 0.015^{b c y}$ \\
\hline & 7 & $20.46 \pm 0.557^{2 x}$ & $20.63 \pm 0.142^{2 x}$ & $19.62 \pm 0.047^{6 x}$ & $19.46 \pm 0.051^{6 x}$ & $19.42 \pm 0.026^{6 x}$ & $19.51 \pm 0.026^{6 x}$ \\
\hline & 10 & $18.70 \pm 0.025^{2 x}$ & $17.91 \pm 0.050^{6 w}$ & $16.61 \pm 0.026^{c w}$ & $16.14 \pm 0.555 \mathrm{cdw}$ & $16.35 \pm 0.042^{d w}$ & $16.45 \pm 0.035 \mathrm{cdw}$ \\
\hline & 17 & $13.81 \pm 0.015^{28}$ & $12.89 \pm 0.015^{6 v}$ & $11.46 \pm 0.036^{c v}$ & $11.35 \pm 0.031 \mathrm{dv}$ & $11.13 \pm 0.112^{\circ v}$ & $11.29 \pm 0.015^{d v}$ \\
\hline \multirow{5}{*}{$\begin{array}{l}\text { Total } \\
\text { acidity } \\
{[\mathrm{g} / \mathrm{L}]}\end{array}$} & 1 & $5.40=0.100^{x z}$ & $5.77 \pm 0.058^{6 x}$ & $5.13 \pm 0.153^{\mathrm{cr}}$ & $4.98 \pm 0.104^{c x}$ & $4.48 \pm 0.029 d^{d z}$ & $4.74 \pm 0.228^{\circ x}$ \\
\hline & 4 & $5.07 \pm 0.058^{25}$ & $5.33 \pm 0.058^{\circ} \mathrm{y}$ & $4.85 \pm 0.050^{c y}$ & $4.57 \pm 0.061^{d y}$ & $4.40 \pm 0.010^{\circ y}$ & $4.35 \pm 0.025^{\circ y}$ \\
\hline & 7 & $4.82 \pm 0.005^{2 x}$ & $4.95 \pm 0.050^{6 x}$ & $4.58 \pm 0.047^{c x}$ & $4.41 \pm 0.010^{\mathrm{d} x}$ & $4.31 \pm 0.010^{0 x}$ & $4.17 \pm 0.038^{1 x}$ \\
\hline & 10 & $4.61 \pm 0.015^{2 w}$ & $4.72 \pm 0.012^{6 w}$ & $4.39 \pm 0.015^{c w}$ & $4.28 \pm 0.017 \mathrm{dw}$ & $4.14 \pm 0.047^{\circ w}$ & $4.06 \pm 0.015^{\mathrm{fw}}$ \\
\hline & 17 & $4.26 \pm 0.053^{6 v}$ & $4.40 \pm 0.025^{25}$ & $4.03 \pm 0.026^{\mathrm{cv}}$ & $4.03 \pm 0.042^{\mathrm{cv}}$ & $3.80 \pm 0.010^{\circ v}$ & $3.93 \pm 0.032 \mathrm{dv}$ \\
\hline \multirow{5}{*}{$\begin{array}{c}\text { Tartaric } \\
\text { acid } \\
\text { [g/L] }\end{array}$} & 1 & $3.57 \pm 0.153 \mathrm{dw}$ & $3.68 \pm 0.035 \mathrm{~cd}$ & $4.67 \pm 0.031 \mathrm{av}$ & $3.79 \pm 0.026^{c v}$ & $4.50 \pm 0.055^{\mathrm{bv}}$ & $3.81 \pm 0.012^{c v}$ \\
\hline & 4 & $3.88 \pm 0.025^{\circ x}$ & $3.90 \pm 0.010^{\circ} \mathrm{w}$ & $4.87 \pm 0.015^{x+x}$ & $3.98 \pm 0.015^{d x}$ & $4.72 \pm 0.006^{6 x}$ & $4.01 \pm 0.010^{\mathrm{cw}}$ \\
\hline & 7 & $4.10 \pm 0.015^{1 y}$ & $4.13 \pm 0.015^{\circ x}$ & $4.99 \pm 0.006^{\text {xxy }}$ & $4.20 \pm 0.006^{d x}$ & $4.91=0.010^{6 x}$ & $4.26 \pm 0.012^{c x}$ \\
\hline & 10 & $4.19 \pm 0.006^{\mathrm{xy}}$ & $5.12 \pm 0.006^{\mathrm{by}}$ & $5.15 \pm 0.021 \mathrm{ay}$ & $4.36 \pm 0.006^{\bullet y}$ & $5.10 \pm 0.006^{c y}$ & $4.42 \pm 0.006^{d y}$ \\
\hline & 17 & $4.45=0.020^{c z}$ & $5.27=0.006^{2 x}$ & $5.33 \pm 0.021^{1 x}$ & $4.86 \pm 0.318^{6 z}$ & $5.20 \pm 0.010^{x x}$ & $4.61 \pm 0.010^{c x}$ \\
\hline \multirow{5}{*}{$\begin{array}{c}\text { Total } \\
\text { phenol } \\
\text { content } \\
{[\mathrm{mg}} \\
\text { GAE } / \mathrm{L}]\end{array}$} & 1 & $0.407 \pm 0.002^{\mathrm{IV}}$ & $0.750 \pm 0.003^{2=}$ & $0.525 \pm 0.003$ dv & $0.578 \pm 0.002^{c v}$ & $0.687 \pm 0.003^{6 \mathrm{~V}}$ & $0.511 \pm 0.002^{\circ v}$ \\
\hline & 4 & $0.618 \pm 0.002^{1 w}$ & $0.760 \pm 0.002^{2 x}$ & $0.677 \pm 0.003^{\circ w}$ & $0.700 \pm 0.002^{d w}$ & $0.754 \pm 0.002^{6 *}$ & $0.713 \pm 0.001^{\mathrm{cw}}$ \\
\hline & 7 & $0.783 \pm 0.002^{d x}$ & $0.764 \pm 0.001^{\mathrm{ix}}$ & $0.765 \pm 0.003^{\circ x}$ & $0.831 \pm 0.001^{6 x}$ & $0.890 \pm 0.002^{3 x}$ & $0.793 \pm 0.001^{c x}$ \\
\hline & 10 & $0.815 \pm 0.002 \cdot 5$ & $0.771 \pm 0.002^{\mathrm{zy}}$ & $1.097 \pm 0.001 \cdot y$ & $1.124 \pm 0.003^{d y}$ & $1.274 \pm 0.002^{\mathrm{xy}}$ & $1.143 \pm 0.002^{b y}$ \\
\hline & 17 & $0.951 \pm 0.003^{\circ x}$ & $0.781 \pm 0.003^{\mathrm{fx}}$ & $1.233 \pm 0.002^{d x}$ & $1.307 \pm 0.002^{6 x}$ & $1.592 \pm 0.002^{3 x}$ & $1.296 \pm 0.002^{\mathrm{cx}}$ \\
\hline
\end{tabular}

further studies are required to establish the most efective conditions to comply with specifications in terms of microbial load and other caracteristics of juice processed byultrasound.

Natural juices with high increase content of vitamin C could have an important impact on human health and therefore, would be of interest (for consumers, producers and policymakers) to have more information about the methods for improving the content of these valuable antioxidant using modern methods like the ultrasound treatments.

Ultrasound treatment had a significant effect on grapes juice $\mathrm{pH}$ after all the storage time, compared with untreated juice (table 3). Values of $\mathrm{pH}$ juice ranged between $3.633 \pm 0.006$ to $3.447 \pm 0.006$. During storage, $\mathrm{pH}$ values and total acidity decrease in all treatment variants. Our results regarding $\mathrm{pH}$ and total acidity of sonicated samples are in accordance with observations of sonicated kasturi lime juice [17] and apple juice [18].

Ultrasound treatments had significantly effect on the total soluble solids ( $\left.{ }^{\circ} \mathrm{Bx}\right)$ compared with the untreated and pasteurized samples, the highest decrease was observed in case of variant $80 \%$ amplitude for $18 \mathrm{~min}$, after 4,10 and 17 storage days. For all variants of treatments, this parameter decreased significantly during storage. The values of total solids content of juice $\left({ }^{\circ} \mathrm{Bx}\right)$ ranged between $24.40 \pm 0.000$ for pasteurized variant and $11.13 \pm 0.112$ for variant $\mathrm{A} 80 \%, 18 \mathrm{~min}$ (table 3 ). It has been reported that sonication treatment cause a significant decrease in ${ }^{\circ}$ Brix also of kasturi lime juice [17].

During storage, tartaric acid content increased significantly. A very strong increasement was observed after each storage days in case of samples treated by ultrasound 18 min at both amplitude (A60\% and $\mathrm{A} 80 \%$ ).
After 10 and 17 storage days, the pasteurized juices showed a similar increase. This increase of tartaric acid content could indicate a start of fermentation none recommended in our case.

As shown in table 3 , a significant increase $(p<0.05)$ was observed in total phenolic content in the entire grape juice sample sonicated at both amplitude and at both time, also at untreated grape juice. The highest increase was observed in the case of variant $A 80 \% 18 \mathrm{~min}$; this increase was in range from $0.687 \mathrm{mg} \mathrm{GAE} / \mathrm{L}$ up to $1.592 \mathrm{mg} \mathrm{GAE} / \mathrm{L}$. The exception is the pasteurized grape juices (in this case, the increase was not significant). The increase of the total phenolic content was found also in the apple juice [18]. The possible reason for significant increases in these phenolic phytonutrients might be attributed to the enhanced disruption of cell wall due to cavitations as a result of rapid change in pressures of the liquid by shear forces exerted during sonication which might lead to the release of some chemically bound polyphenolic phytonutrients and ultimately increased their availability in the juice. Creation of hydroxyl radicals by bubble implosion during sonication to the aromatic ring of phenolic compounds might also be a cause of their improvement in the apple juice. It has already been reported that increase in antioxidant capacity of phenolic compounds might be attributed to the addition of second hydroxyl group in different positions of these compounds chemical structure $[17,18]$.

\section{Conclusions}

Results of this study show a significant difference between the total vitamin $\mathrm{C}$ content of the grapes juices treated by different methods, minimally processed 
technology (pasteurization / ultrasound used for improve the product shelf life).

Ultrasound treatments, particullary at $80 \%$ amplitude for 36 min. had a significant effect on vitamin C content during the storage (ending up with values of $64.498 \pm 4.022$ $\mathrm{mg}$ L-AA/L after 17 storage days). How ever, the results presented arise from working with a few of biological samples. Also, it is necessary to continue this research with extended experiments.

\section{References}

1.AGUILAR, K., GARVIN, A., IBARZ, A., AUGUSTO, P.E.D., Ultrasonics Sonochemistry 37, no. 7, 2017, p. 375.

2.VINATORU, M., Ultrasonics Sonochemistry, 8, no. 3, 2001, p. 303313.

3.VILKHU, K., MAWSON, R., SIMONS, L., BATES, D., Innovative Food Science and Emerging Technologies, 9, no. 2, 2008, p. 161-169.

4.CHEOK, C.Y., CHIN, N.L., YUSOF, Y.A., TALIB, R.A., LAW, C.L., Industrial crops and Products, 50, 2013, p. 1-7.

5.DAMSA, F.,W OINAROSCHY, A., OLTEANU, GH., BADARAU, C.L., Rev. Chim. (Bucharest), 67, no. 4, 2016, p. 665-669.

6.TIWARI, B.K., O'DONNELL, C.P., PATRAS, A., CULLEN, P.J ., Journal of Agricultural and Food Chemistry 56, no. 21, 2008, p. 10071-10077. 7.CAMIRE, M.E., KUBOW, S., DONNELLY, D.J., Critical Reviews in Food Science Nutrition 49, no. 10, 2009, p. 821- 840.
8.CAHILL, L., COREY, P.N., El-SOHEMY, A., American Journal Epidemiology 170, no. 4, 2009, p. 464-471.

9.SCHLEICHER, R.L., CARROLL, M.D., FORD, E.S., LACHER, D.A., American J ournal Clinic Nutrition 90, no. 5, 2009, p.1252-1263.

10.*** EC, Commission directive 2008/1001 EC of 28 October 2008, Official Journal of the European Union. http://eurlex. europa. eulLEXUriServ/LexUriServ.do?uri =0] :L: 2008:285: 0009:0012: EN:PDF. 11.MCLENNAN, W., PODGER, A., Australian Bureau of Statistics, 1998. http://www.ausstats.abs.gov.au/ausstats/subscriber.nsf/O/CA.

12.BADARAU, C.L., TICAN, A., STEFAN, M., CHIRU, N., Scientific Papers. Series A. Agronomy 60, 2017 p. 199.

13.ABID, M., JABBAR, S., WU, T., HASHIM, M.M., HU, B., LEI, S., ZHANG, X., ZENG, X., Ultrasonics Sonochemistry 20, no. 5, 2013, p. 1182-1187. 14.CHENG, L.H., SOH, C.Y., LIEW, S.C., TEH, F.F., Food Chemistry 104, no. 4, 2007, p. 1398.

15.KORN, M., PRIM, P.M., DE SOUSA, C.S., Microchemical Journal 73, no. 3, 2002, p. 273-277.

16.SANCHEZ-MATA, M.C., CAMARA-HURTADO, M., DIEZ-MARCHEZ, C., TORIJA-ISASA, M.E., European Food Research and Technology 210, 2000, p. 220-225.

17.BHAT, R., KAMARUDDIN, L., MIN-TZE, N.S.B.C, KARIM, A.A., Ultrasonics Sonochemistry 18, no. 6, 2011, p. 1297.

18.ABID, M., JABBAR, S., WU, T., HASHIM, M.M., HU, B.H., LEI, S., ZHANG, X., ZENG, X., Ultrasonics Sonochemistry 20, , p.1184.

Manuscript received: 19.12 .2018 